\title{
Impact of Noninvasive Ventilation on Lung Volumes and Maximum Respiratory Pressures in Duchenne Muscular Dystrophy
}

\author{
Dante Brasil Santos PT PhD, Isabelle Vaugier, Ghilas Boussaïd PT, David Orlikowski MD PhD, \\ Hélène Prigent MD PhD, and Frédéric Lofaso MD PhD
}

\begin{abstract}
BACKGROUND: Duchenne muscular dystrophy (DMD) is a sex-linked genetic disorder in which progressive impairment of skeletal muscle function eventually leads to severe respiratory failure requiring continuous noninvasive ventilation (NIV) at home. A current focus of debate is whether NIV may slow the decline in respiratory function or, on the contrary, worsen respiratory function when started early. Our objective here was to describe the effects of NIV on vital capacity (VC) and maximum respiratory pressures in DMD. METHODS: We analyzed retrospective data from 71 subjects with DMD, including VC, maximum static respiratory pressures, and sniff nasal inspiratory pressure before and after NIV initiation. The declines in these variables from the highest value to the most recent value were computed. RESULTS: Although respiratory function continued to deteriorate over time, NIV introduction was followed by significant slowing in the annual rates of decline in $\mathrm{VC}$ (from 4.28 to 1.36 percent predicted), maximum inspiratory pressure (from 2.77 to $1.48 \mathrm{~cm} \mathrm{H}_{2} \mathrm{O}$ ), and maximum expiratory pressure (from 2.00 to $1.00 \mathrm{~cm} \mathrm{H}_{2} \mathrm{O}$ ). NIV had no effect on sniff nasal inspiratory pressure. CONCLUSIONS: Introducing NIV in subjects with DMD was followed by slowing of the declines in $\mathrm{VC}$ and in maximum static inspiratory and expiratory pressures. Key words: Duchenne muscular dystrophy; neuromuscular disease; noninvasive ventilation; follow-up. [Respir Care 2016;61(11):1530-1535. ( 2016 Daedalus Enterprises]
\end{abstract}

\section{Introduction}

Duchenne muscular dystrophy (DMD) is a sex-linked genetic disorder in which abnormalities in the sarcolem-

\footnotetext{
Mr Brasil Santos, Mr Boussaïd, Dr Prigent, and Dr Lofaso are affiliated with INSERM U 1179-Université de Versailles Saint Quentin en Yvelines, Versailles, France. Mr Brasil Santos is also affiliated with the Centro de Fisioterapia e Reabilitação-Hospital Universitário de Brasília, Universidade de Brasília, Brasilia, Brazil. Ms Vaugier and Dr Orlikowski are affiliated with CIC 1429-INSERM-APHP, Hôpital Raymond Poincaré, Garches, France. Dr Orlikowski is affiliated with the Service de Réanimation, APHP-Hôpital Raymond Poincaré, Garches, France. Drs Prigent and Lofaso are affiliated with Physiologie-Explorations Fonctionnelles, APHP, Hôpital Raymond Poincaré, Garches, France.
}

Mr Brasil Santos received a grant from the Brazilian National Council of Scientific and Technological Development. The authors have disclosed no conflicts of interest.

Correspondence: Frédéric Lofaso MD PhD, Service Physiologie-Explorations Fonctionnelles, CHU R. Poincaré, 104 Boulevard Raymond Poincaré, 92380 Garches, France. E-mail: f.lofaso@aphp.fr.

DOI: $10.4187 /$ respcare.04703 ma-spanning protein complex dystrophin cause progressive deterioration of skeletal muscle strength and structure. ${ }^{1}$ Among the resulting impairments, gradual weakening of the respiratory muscles ${ }^{2}$ eventually leads to chronic respiratory failure requiring noninvasive ventilation (NIV) at home. Typically, NIV is first introduced only at night, as soon as the patient starts to exhibit signs of hypoventilation during sleep. ${ }^{3}$ Over time, hypoventilation occurs also during wakefulness, requiring daytime NIV, intermittently at first and then continuously. ${ }^{4}$ Among causes of death in patients on continuous NIV, respiratory failure is the most common, followed by cardiomyopathy. ${ }^{5}$ Survival has improved significantly since the introduction of NIV once hypercapnia occurs. ${ }^{6,7}$ Changes over time in lung function parameters and maximum static respiratory pressures in patients with DMD have been investigated,,$^{2,8}$ as well as the impact on these variables of cardiac interventions and NIV. ${ }^{7,9}$ Intermittent positive-pressure breathing therapy improved lung volumes in short-term ${ }^{10}$ and longterm $^{11,12}$ studies of subjects with DMD. However, the effect of NIV on respiratory function is unclear. One study in 14 DMD subjects suggested that nocturnal nasal venti- 
lation reduced the decline of vital capacity (VC), ${ }^{13}$ whereas another study on a highly heterogeneous population of subjects with neuromuscular disease showed no significant benefits from nocturnal intermittent positive-pressure ventilation. ${ }^{14}$ Importantly, a 1994 study of subjects with DMD raised concerns about the safety of nocturnal NIV that was started early, with the goal of slowing the decline in respiratory function. ${ }^{15}$

In this study of subjects with DMD, our objective was to describe the impact of NIV on lung volumes and on airway pressures (maximum inspiratory pressure $\left[\mathrm{P}_{\text {Imax }}\right]$, maximum expiratory pressure $\left[\mathrm{P}_{\text {Emax }}\right]$, and sniff nasal inspiratory pressure). We retrospectively analyzed data obtained before and after NIV initiation.

\section{Methods}

This study was approved by the French Data Protection Authority (Commission Nationale de l'Informatique et des Libertés), in accordance with French legislation. Informed consent was not required, according to French law on retrospective evaluations of anonymized data.

\section{Subjects}

We included consecutive patients with DMD who received follow-up at the home-ventilation unit of the Raymond Poincaré University Hospital, Garches, France, between September 1992 and June 2014; were >16 y of age; and were referred for long-term monitoring of respiratory function before and after NIV initiation to detect and treat respiratory failure. DMD was diagnosed based on clinical findings, massive creatine phosphokinase elevation, absence of dystrophin staining by immunocytochemistry of muscle biopsy specimens, and identification of dystrophin gene mutations. ${ }^{16}$ We did not include patients with intermediate forms of DMD, Becker muscular dystrophy, or tracheostomy.

According to our regional guidelines, all subjects received prophylactic cardiac treatment with angiotensinconverting enzyme inhibitors, and none received corticosteroids. None of the subjects were smokers.

\section{Data Collection}

The data were collected retrospectively from the medical records. We recorded lung function test results, $\mathrm{P}_{\text {Imax }}$, $\mathrm{P}_{\text {Emax }}$, and sniff nasal inspiratory pressure values measured before NIV initiation and during follow-up. All data were obtained at the lung function testing laboratory; we did not use data collected in the ICU, since patients requiring critical care may have acute unstable conditions.

The standard follow-up of patients with NIV in our department includes routine lung function and respiratorymuscle tests at each visit. The frequency of the visits is at

\section{QUICK LOOK}

\section{Current knowledge}

Hyperinflation by intermittent positive-pressure breathing therapy improves lung volumes in Duchenne muscular dystrophy. However, the effect of home noninvasive ventilation on respiratory function is unclear.

\section{What this paper contributes to our knowledge}

Home noninvasive ventilation was followed by slowing of the declines in lung volumes and maximum static respiratory pressures in subjects with Duchenne muscular dystrophy.

the discretion of the physician in charge of the patient. Lung function testing is performed according to American Thoracic Society/European Respiratory Society recommendations, ${ }^{17}$ using a Vmax 229 Sensormedics system (Yorba Linda, California) with the patient in the upright position, ${ }^{18} \mathrm{VC}$ was measured also in the supine position. $\mathrm{VC}$ is expressed as a percentage of the predicted value. ${ }^{18}$ $\mathrm{P}_{\text {Imax }}$ and sniff nasal inspiratory pressure ${ }^{19,20}$ were measured from the functional residual capacity in the upright position, and $\mathrm{P}_{\text {Emax }}$ was measured at total lung capacity, and they are expressed as percentages of the predicted values. $^{21,22}$ For each parameter, the best value was recorded. ${ }^{23,24}$ Airway pressures used to assess respiratory muscle function are reported in $\mathrm{cm}_{2} \mathrm{O}$. Nocturnal NIV was initiated based on published criteria, ${ }^{25}$ however we did not use the VC and maximal mouth pressure thresholds usually recommended for progressive neuromuscular disorders, ${ }^{25}$ which are not appropriate for DMD and, accordingly, were not included in the 2004 ATS guidelines for patients with this disease. ${ }^{11}$

\section{Statistics}

A segmented linear-mixed effect regression model was used to analyze changes over time in VC (percent predicted) and in $\mathrm{P}_{\text {Imax }}, \mathrm{P}_{\text {Emax }}$, and sniff nasal inspiratory pressure $\left(\mathrm{cm} \mathrm{H}_{2} \mathrm{O}\right)$. The time variable was the time from NIV initiation. A random intercept and a random slope were used for each subject. Pre-NIV and post-NIV values were estimated with their $95 \% \mathrm{CIs}$, and the paired $t$ test was chosen to compare pre-NIV and post-NIV slopes. The level of significance was set at $5 \%$.

\section{Results}

We obtained data from 71 subjects with DMD, including 33 (46\%) already receiving NIV at the first visit. At the 

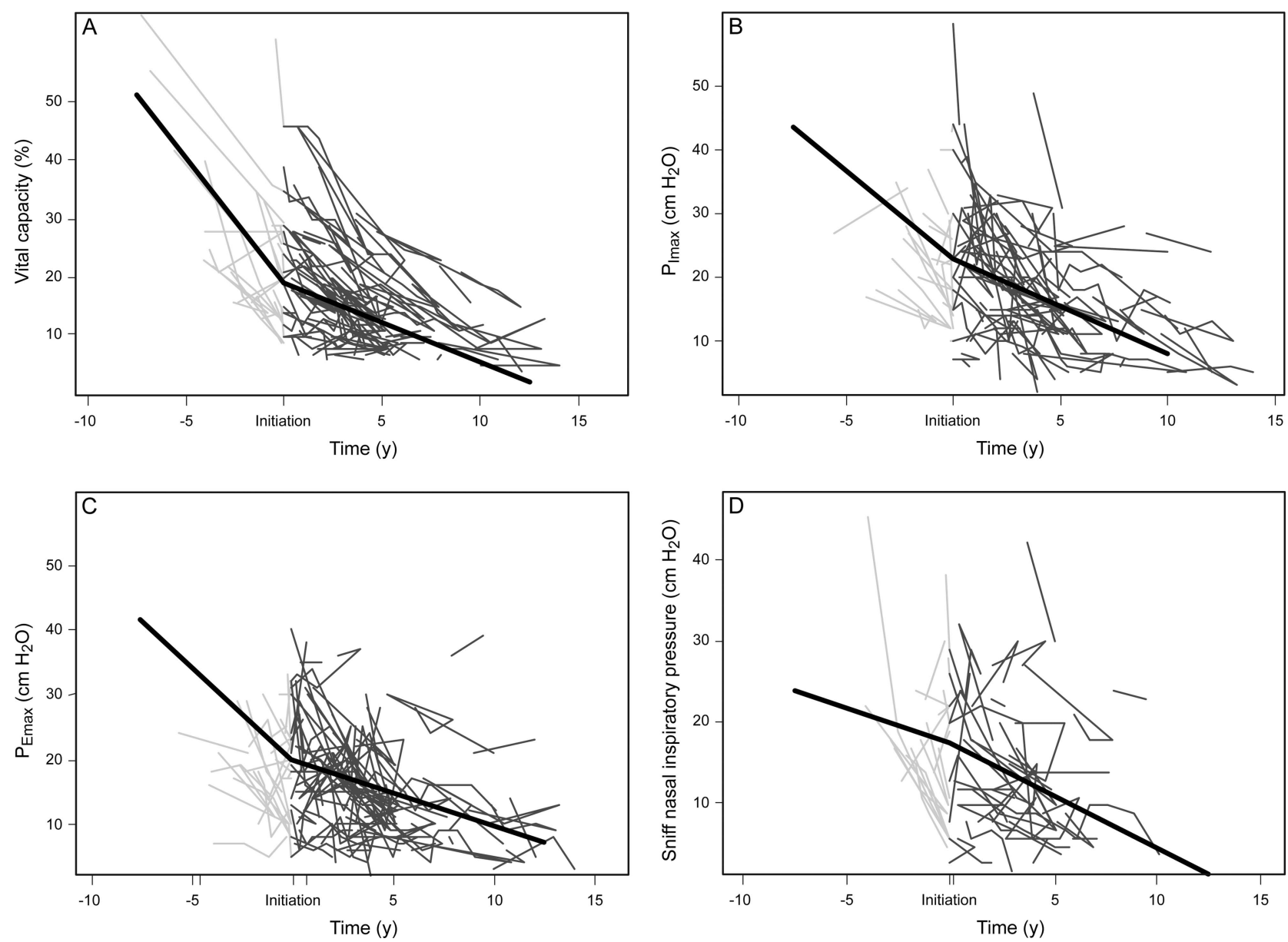

Fig. 1. Individual and mean (bold lines) values for vital capacity $(A)$, maximum inspiratory pressure $\left(P_{I \max }\right)(B)$, maximum expiratory pressure $\left(P_{E \max }\right)(C)$, and sniff nasal inspiratory pressure $(D)$ over time, before and after initiation of NIV at home.

first visit, mean age was $20.7 \pm 3.4$ y in subjects not yet started on NIV and $21.6 \pm 3.8 \mathrm{y}$ in those already receiving NIV (usually started in the pediatric units). Mean age at NIV initiation was $20 \pm 4 \mathrm{y}$, and NIV follow-up duration in our laboratory overall was $4 \pm 3 \mathrm{y}$. Lung function tests with $\mathrm{VC}$ values were available for all 71 subjects, $\mathrm{P}_{\text {Imax }}$ and $\mathrm{P}_{\text {Emax }}$ values were available for 68 subjects, and sniff nasal inspiratory pressure values were available for 41 subjects (Fig. 1). At least 2 values of the study variables were available for 64 subjects $(90 \%)$. In the overall population $(N=71)$, the age range at the first home ventilation unit visit was $16-39$ y. Table 1 reports the main subject characteristics at the time of the first tests.

Table 2 reports the results of the mixed model analysis comparing the changes in variables over time before and after NIV initiation. At the end of follow-up, the subjects used NIV for $11.2 \pm 4.9 \mathrm{~h} / \mathrm{d}$. VC, $\mathrm{P}_{\text {Imax }}, \mathrm{P}_{\text {Emax }}$, and sniff nasal inspiratory pressure declined over time. However, the annual decreases in $\mathrm{VC}, \mathrm{P}_{\mathrm{Imax}}$, and $\mathrm{P}_{\mathrm{Emax}}$ were significantly smaller after NIV initiation.
Table 1. Main Features of the Subjects With Duchenne Muscular Dystrophy at the Time of the First Tests

\begin{tabular}{lllllll}
\hline \hline \multicolumn{1}{c}{ Characteristics } & $\begin{array}{c}\text { Overall } \\
\text { Population }\end{array}$ & $n$ & $\begin{array}{c}\text { No Home } \\
\text { NIV }\end{array}$ & $n$ & $\begin{array}{c}\text { Home } \\
\text { NIV }\end{array}$ & $n$ \\
\hline Age, y & $20.7 \pm 3.4$ & 71 & $20.0 \pm 2.8$ & 38 & $21.6 \pm 3.8$ & 33 \\
VC, \% predicted & $20.8 \pm 12.7$ & 71 & $27.0 \pm 13.0$ & 38 & $14.1 \pm 8.3$ & 33 \\
$\mathrm{P}_{\text {Imax }}, \mathrm{cm} \mathrm{H}_{2} \mathrm{O}$ & $22.0 \pm 11.4$ & 68 & $26.5 \pm 11.0$ & 32 & $17.9 \pm 10.3$ & 36 \\
$\mathrm{P}_{\text {Emax }}, \mathrm{cm} \mathrm{H}_{2} \mathrm{O}$ & $19.5 \pm 9.9$ & 68 & $23.3 \pm 8.8$ & 32 & $16.1 \pm 9.7$ & 36 \\
$\mathrm{SNIP}, \mathrm{cm} \mathrm{H}_{2} \mathrm{O}$ & $16.7 \pm 9.9$ & 41 & $19.6 \pm 7.2$ & 17 & $14.7 \pm 11.2$ & 24 \\
& & & & & & \\
$\begin{array}{l}\text { Data are mean } \pm \text { SD. } \\
\text { VC }=\text { vital capacity }\end{array}$ & & & & & & \\
$\mathrm{P}_{\text {Imax }}=$ maximum inspiratory pressure & & & & & \\
$\mathrm{P}_{\text {Emax }}=$ maximum expiratory pressure \\
$\mathrm{SNIP}=$ sniff inspiratory pressure & & & & & \\
\hline
\end{tabular}

Three subjects using NIV died during follow-up, after 35,27 , and 24 y ( 2 due to heart failure and one due to acute respiratory failure). In addition, 24 subjects underwent tracheostomy, according to international criteria. ${ }^{11,26,27}$ 


\section{Resipratory Function and NIV in Subjects With DMD}

Table 2. Annual Declines in Vital Capacity, Maximum Inspiratory Pressure, Maximum Expiratory Pressure, and Sniff Inspiratory Pressure Before and After Initiation of NIV

\begin{tabular}{|c|c|c|c|c|c|}
\hline Parameter & $\begin{array}{c}\text { Before } \\
\text { NIV } \\
\text { Initiation }\end{array}$ & $95 \% \mathrm{CI}$ & $\begin{array}{c}\text { After } \\
\text { NIV } \\
\text { Initiation }\end{array}$ & $95 \% \mathrm{CI}$ & $P$ \\
\hline $\mathrm{VC}, \%$ predicted & 4.28 & $2.76-5.92$ & 1.36 & $0.98-1.74$ & $<.001$ \\
\hline $\mathrm{VC}, \mathrm{L}$ & 0.16 & $0.11-0.21$ & 0.06 & $0.04-0.07$ & $<.001$ \\
\hline $\mathrm{P}_{\text {Imax }}, \%$ predicted & 2.4 & $2.1-2.7$ & 1.3 & $1.1-1.5$ & $<.001$ \\
\hline $\mathrm{P}_{\text {Imax }}, \mathrm{cm} \mathrm{H}_{2} \mathrm{O}$ & 2.77 & $1.47-4.39$ & 1.48 & $1.05-1.95$ & $<.001$ \\
\hline $\mathrm{P}_{\text {Emax }}, \%$ predicted & 1.8 & $1.5-2.1$ & 0.6 & $0.5-0.7$ & $<.001$ \\
\hline $\mathrm{P}_{\text {Emax }}, \mathrm{cm} \mathrm{H}_{2} \mathrm{O}$ & 2.00 & $0.76-3.59$ & 1.00 & $0.58-1.42$ & $<.001$ \\
\hline SNIP, $\%$ predicted & 0.7 & -0.01 to 1.47 & 1.12 & $0.99-1.26$ & .35 \\
\hline $\mathrm{SNIP}, \mathrm{cm} \mathrm{H}_{2} \mathrm{O}$ & 0.84 & -2.02 to 3.53 & 1.28 & $0.76-1.92$ & .35 \\
\hline \multicolumn{6}{|c|}{$\begin{array}{l}\mathrm{NIV}=\text { noninvasive home ventilation } \\
\mathrm{VC}=\text { vital capacity } \\
\mathrm{P}_{\mathrm{Imax}}=\text { maximal inspiratory pressure } \\
\mathrm{P}_{\mathrm{Emax}}=\text { maximal expiratory pressure } \\
\mathrm{SNIP}=\text { sniff inspiratory pressure } \\
\mathrm{ns}=\text { not significant }\end{array}$} \\
\hline
\end{tabular}

\section{Discussion}

Lung function tests may reflect the severity of respiratory muscle weakness in patients with DMD. ${ }^{28}$ NIV is usually started when evidence of nocturnal hypoventilation develops, even in the absence of symptoms. ${ }^{3}$ The beneficial effects of NIV in patients with DMD are welldocumented. 3,6,9,29 However, whether NIV initiation at an early stage of respiratory muscle weakness improves or worsens patient outcomes is debated. ${ }^{15}$

Signs of respiratory muscle dysfunction usually develop at about $14 \mathrm{y}$ of age in patients with DMD. ${ }^{2,30}$ They consist of decreases in maximum static respiratory pressures ${ }^{31}$ and in lung volumes. ${ }^{4}$ Data about the effects of positivepressure support on lung function in patients with DMD come from a 1994 study in only 10 subjects, ${ }^{32}$ a pediatric study, ${ }^{10}$ and studies using intermittent positivepressure breathing rather than NIV. ${ }^{10,12}$ Another study ${ }^{13}$ collected similar data from 14 subjects with DMD treated with nocturnal NIV and showed benefits in the VC decline (reported in $\mathrm{mL}$ ). In our study, we presented data from a larger DMD population, showing the effects not only on VC but also on maximum static respiratory pressures. Positive-pressure insufflation was usually beneficial; the only exception was a study in an extremely heterogeneous population of subjects with various neuromuscular diseases. ${ }^{14}$

Our results support previous evidence of benefits from NIV. ${ }^{13}$ Importantly, the decline in lung function was slower after NIV initiation. Although we cannot establish a causal relationship between NIV initiation and slowing of lung function decline, our results support earlier NIV initiation during the course of DMD. VC, $\mathrm{P}_{\text {Imax }}, \mathrm{P}_{\text {Emax }}$, and sniff nasal inspiratory pressure were higher in the group of sub- jects who did not start NIV than in the group receiving NIV. This finding may be related to the respiratory function criteria used to initiate NIV. ${ }^{25}$ Both lung volumes and maximum airway pressures decreased more slowly after NIV initiation. The pace of sniff nasal inspiratory pressure decline, in contrast, was unchanged. However, sniff nasal inspiratory pressure may lack reliability for evaluating inspiratory muscle strength in patients with DMD, ${ }^{23}$ since failure of the nostrils to collapse at pressures below $15 \mathrm{~cm}$ $\mathrm{H}_{2} \mathrm{O}$ may result in spuriously low sniff nasal inspiratory pressure values. ${ }^{33}$ Most of our subjects had values $<15 \mathrm{~cm}$ $\mathrm{H}_{2} \mathrm{O}$ (Fig. 1D). One hypothesis to explain the lung-volume improvements is that NIV might contribute to preserve lung and chest-wall compliance, thereby slowing the lungvolume decreases associated with progressive respiratory muscle weakness. Support for this hypothesis comes from previous evidence that similar lung-volume improvements occur with intermittent positive-pressure breathing. ${ }^{10,12}$ The application of positive pressure might slow the development of the restrictive respiratory pattern due in DMD to rib-cage deformities and respiratory muscle weakness.

Regarding respiratory muscle function, a study in a mouse model of DMD suggests that forced lengthening of the diaphragm fibers induced by the elastic recoil of the thorax as the diaphragm contracts may lead to eccentric contraction injury. ${ }^{34}$ Eccentric contraction per se may injure the contractile and cytoskeletal components of the muscle fibers. ${ }^{35}$ The absence of functional dystrophin in patients with DMD may lower the mechanical-stress threshold above which eccentric contraction induces injury. ${ }^{36}$ We can speculate that the slowing of the declines in $\mathrm{P}_{\text {Imax }}$ and $\mathrm{P}_{\text {Emax }}$ after NIV initiation might indicate an ability of mechanical support to protect the respiratory muscles from further injury.

There are some limitations to this study, including the retrospective design. In addition, the intensity of follow-up varied considerably between subjects. Thus, some subjects came to the clinic every 2 months and others only once/y. This heterogeneity prompted us to use a mixed model for the statistical analysis. The absence of data before NIV from subjects started on this treatment early is also a major limitation. Many of our subjects were initially followed up at the pediatric units and were then referred to our adult unit after NIV initiation, explaining the lack of information before NIV. We generated the slopes for post-NIV respiratory muscle strength by combining data from subjects with and without pre-NIV assessments. The results were then compared with those in the subgroup of subjects with pre-NIV data. There were no substantial differences. Thus, in the group with data from both periods, the values before and after NIV were $4.3 \%$ versus $1.4 \%$ for VC, $2.4 \mathrm{~cm} \mathrm{H}_{2} \mathrm{O}$ versus $1.7 \mathrm{~cm} \mathrm{H}_{2} \mathrm{O}$ for $\mathrm{P}_{\text {Imax }}$, and $2.8 \mathrm{~cm} \mathrm{H}_{2} \mathrm{O}$ versus $1.1 \mathrm{~cm} \mathrm{H}_{2} \mathrm{O}$ for $\mathrm{P}_{\mathrm{Emax}}$ (all $P$ values $<.001$ ). Finally, in our study, NIV duration was $4.0 \pm 3.0 \mathrm{y}$, which is short 


\section{Resipratory Function and NIV in SubJects With DMD}

for a population with DMD. This finding is ascribable to the fact that 3 subjects died while receiving NIV and 24 others underwent tracheostomy. Nevertheless, NIV duration in our study was consistent with that in another study from a similar European center. ${ }^{37}$

\section{Conclusions}

In our study, the introduction of NIV was followed by slowing of the declines in lung volumes and maximum static respiratory pressures in subjects with DMD. Studies are needed to assess whether these associations between NIV and improvements in lung volumes are affected by the stage of respiratory dysfunction at the time of NIV initiation.

\section{REFERENCES}

1. Bushby KM. Genetic and clinical correlations of Xp21 muscular dystrophy. J Inherit Metab Dis 1992;15(4):551-564.

2. Inkley SR, Oldenburg FC, Vignos PJ Jr. Pulmonary function in Duchenne muscular dystrophy related to stage of disease. Am J Med 1974;56(3):297-306.

3. Aboussouan LS. Sleep-disordered breathing in neuromuscular disease. Am J Respir Crit Care Med 2015;191(9):979-989.

4. Bach JR, Martinez D. Duchenne muscular dystrophy: continuous noninvasive ventilatory support prolongs survival. Respir Care 2011; 56(6): 744-750.

5. Roberto R, Fritz A, Hagar Y, Boice B, Skalsky A, Hwang H, et al. The natural history of cardiac and pulmonary function decline in patients with Duchenne muscular dystrophy. Spine 2011;36(15): E1009-E1017.

6. Eagle M, Baudouin SV, Chandler C, Giddings DR, Bullock R, Bushby K. Survival in Duchenne muscular dystrophy: improvements in life expectancy since 1967 and the impact of home nocturnal ventilation. Neuromuscul Disord 2002;12(10):926-929.

7. Ishikawa Y, Miura T, Ishikawa Y, Aoyagi T, Ogata H, Hamada S, Minami R. Duchenne muscular dystrophy: survival by cardio-respiratory interventions. Neuromuscul Disord 2011;21(1):47-51.

8. Phillips MF, Quinlivan RC, Edwards RH, Calverley PM. Changes in spirometry over time as a prognostic marker in patients with Duchenne muscular dystrophy. Am J Respir Crit Care Med 2001;164(12): 2191-2194

9. Jeppesen J, Green A, Steffensen BF, Rahbek J. The Duchenne muscular dystrophy population in Denmark, 1977-2001: prevalence, incidence and survival in relation to the introduction of ventilator use. Neuromuscul Disord 2003;13(10):804-812.

10. Stehling F, Bouikidis A, Schara U, Mellies U. Mechanical insufflation/exsufflation improves vital capacity in neuromuscular disorders. Chron Respir Dis 2015;12(1):31-35.

11. Finder JD, Birnkrant D, Carl J, Farber HJ, Gozal D, Iannaccone ST, et al. Respiratory care of the patient with Duchenne muscular dystrophy: ATS consensus statement. Am J Respir Crit Care Med 2004; 170(4):456-465.

12. McKim DA, Katz SL, Barrowman N, Ni A, LeBlanc C. Lung volume recruitment slows pulmonary function decline in Duchenne muscular dystrophy. Arch Phys Med Rehabil 2012;93(7):1117-1122.

13. Rideau Y, Delaubier A, Guillou C, Renardel-Irani A. Treatment of respiratory insufficiency in Duchenne's muscular dystrophy: nasal ventilation in the initial stages. Monaldi Arch Chest Dis 1995;50(3): 235-238.
14. Barbé F, Quera-Salva MA, de Lattre J, Gajdos P, Agustí AG. Longterm effects of nasal intermittent positive-pressure ventilation on pulmonary function and sleep architecture in patients with neuromuscular diseases. Chest 1996;110(5):1179-1183.

15. Raphael JC, Chevret S, Chastang C, Bouvet F. Randomised trial of preventive nasal ventilation in Duchenne muscular dystrophy: French Multicentre Cooperative Group on Home Mechanical Ventilation Assistance in Duchenne de Boulogne Muscular Dystrophy. Lancet 1994;343(8913):1600-1604.

16. Abbs S, Tuffery-Giraud S, Bakker E, Ferlini A, Sejersen T, Mueller CR. Best practice guidelines on molecular diagnostics in Duchenne/ Becker muscular dystrophies. Neuromuscul Disord 2010;20(6):422427.

17. Miller MR, Hankinson J, Brusasco V, Burgos F, Casaburi R, Coates A, et al. Standardisation of lung function testing: the authors' replies to readers' comments. Eur Respir J 2010;36(6):1496-1498.

18. Quanjer PH, Tammeling GJ, Cotes JE, Pedersen OF, Peslin R, Yernault JC. Lung volumes and forced ventilatory flows: report Working Party Standardization of Lung Function Tests, European Community for Steel and Coal: official statement of the European Respiratory Society. Eur Respir J Suppl 1993;16:5-40.

19. Héritier F, Rahm F, Pasche P, Fitting JW. Sniff nasal inspiratory pressure: a noninvasive assessment of inspiratory muscle strength. Am J Respir Crit Care Med 1994;150(6 Pt 1):1678-1683.

20. Prigent H, Lejaille M, Falaize L, Louis A, Ruquet M, Fauroux B, et al. Assessing inspiratory muscle strength by sniff nasal inspiratory pressure. Neurocrit Care 2004;1(4):475-478.

21. Evans JA, Whitelaw WA. The assessment of maximal respiratory mouth pressures in adults. Respir Care 2009;54(10):1348-1359.

22. Uldry C, Fitting JW. Maximal values of sniff nasal inspiratory pressure in healthy subjects. Thorax 1995;50(4):371-375.

23. Hart N, Polkey MI, Sharshar T, Falaize L, Fauroux B, Raphaël JC, Lofaso F. Limitations of sniff nasal pressure in patients with severe neuromuscular weakness. J Neurol Neurosurg Psychiatry 2003; 74(12):1685-1687.

24. Stefanutti D, Benoist MR, Scheinmann P, Chaussain M, Fitting JW. Usefulness of sniff nasal pressure in patients with neuromuscular or skeletal disorders. Am J Respir Crit Care Med 2000;162(4 Pt 1): 1507-1511.

25. Clinical indications for noninvasive positive pressure ventilation in chronic respiratory failure due to restrictive lung disease, COPD, and nocturnal hypoventilation: a consensus conference report. Chest 1999; 116(2):521-534.

26. Bushby K, Finkel R, Birnkrant DJ, Case LE, Clemens PR, Cripe L, et al. Diagnosis and management of Duchenne muscular dystrophy, part 2: implementation of multidisciplinary care. Lancet Neurol 2010; 9(2):177-189.

27. Hull J, Aniapravan R, Chan E, Chatwin M, Forton J, Gallagher J, et al. British Thoracic Society guideline for respiratory management of children with neuromuscular weakness. Thorax 2012;67 Suppl 1:i1-i40.

28. Toussaint M, Chatwin M, Soudon P. Mechanical ventilation in Duchenne patients with chronic respiratory insufficiency: clinical implications of 20 years published experience. Chron Respir Dis 2007; 4(3):167-177.

29. Simonds AK, Muntoni F, Heather S, Fielding S. Impact of nasal ventilation on survival in hypercapnic Duchenne muscular dystrophy. Thorax 1998;53(11):949-952.

30. Won YH, Choi WA, Kim DH, Kang SW. Postural vital capacity difference with aging in Duchenne muscular dystrophy. Muscle Nerve 2015;52(5):722-727.

31. Hahn A, Bach JR, Delaubier A, Renardel-Irani A, Guillou C, Rideau Y. Clinical implications of maximal respiratory pressure determinations for individuals with Duchenne muscular dystrophy. Arch Phys Med Rehabil 1997;78(1):1-6. 


\section{Resipratory Function and NIV in SubJects With DMD}

32. Vianello A, Bevilacqua M, Salvador V, Cardaioli C, Vincenti E. Long-term nasal intermittent positive pressure ventilation in advanced Duchenne's muscular dystrophy. Chest 1994;105(2):445448.

33. Bridger GP, Proctor DF. Maximum nasal inspiratory flow and nasal resistance. Ann Otol Rhinol Laryngol 1970;79(3):481-488.

34. Boland B, Himpens B, Denef JF, Gillis JM. Site-dependent pathological differences in smooth muscles and skeletal muscles of the adult mdx mouse. Muscle Nerve 1995;18(6):649-657.
35. Kilmer DD, Aitkens SG, Wright NC, McCrory MA. Response to high-intensity eccentric muscle contractions in persons with myopathic disease. Muscle Nerve 2001;24(9):1181-1187.

36. Petrof BJ, Shrager JB, Stedman HH, Kelly AM, Sweeney HL. Dystrophin protects the sarcolemma from stresses developed during muscle contraction. Proc Natl Acad Sci USA 1993;90(8):3710-3714.

37. Soudon P, Steens M, Toussaint M. A comparison of invasive versus noninvasive full-time mechanical ventilation in Duchenne muscular dystrophy. Chron Respir Dis 2008;5(2):87-93. 